\author{
A.V. Marshinin \\ University of Tyumen, Tyumen, Russia \\ Corresponding author: marshinin@mail.ru
}

\title{
Landscape diversity of the forest-steppe in the Tyumen Oblast (Russia)
}

\begin{abstract}
Forest-steppe landscapes are ecotonic systems that are characterized by a high degree of diversity due to the combination of zonal forest and steppe landscapes, as well as swamps and meadows. The research is based on a comprehensive analysis of literary sources, topographic and thematic maps, satellite images, as well as field expeditions of 1997-2020. In the south-western part of the Tyumen Oblast, 12 types of terrain are differentiated on an area of $30,000 \mathrm{~km}^{2}$, including types of terrain of divides, ridges, flat ridges, flat depressions, hillock depressions, terraces, slopes, lakes and swamps, reed swamps, ravines and girders, floodplains of large rivers, small valleys. The main features of the spatial organization of landscapes in the region and the landscape structure at the level of components are characterized. In the conditions of the region, the main part of landscapes is convenient for economic development and used in various sectors of the economy. Meadow and steppe landscapes, and partly forests are plowed. Pastures and hayfields are widespread on the territory. Such economic activities as sand and peat extraction, wood harvesting, recreational nature use, as well as fishing, hunting, and gathering have been developed. Some landscapes are protected by state as nature reserves.
\end{abstract}

Keywords: type of terrain, landscape structure, forest-steppe, Tyumen Oblast.

\section{Introduction}

Taking into account the landscape structure of territories is important for understanding the features of natural processes, economic activities planning. On the example of the south-western part of the Tyumen Oblast with an area of $30,000 \mathrm{~km}^{2}$, the landscape structure of the territory is characterized in detail at the level of types of terrain as combinations of landscape units and a set of landscape components; the main directions of economic use of landscapes are described.

\section{Experimental}

The landscape diversity of the forest-steppe on the example of the south-western part of the Tyumen Oblast is characterized on the basis of a comprehensive analysis of special literature, topographic and thematic maps, satellite images [1], field explorations in the period of 1997-2020. In the article, the structure of types of terrain is presented [2], the landscape components - features of the relief, geological foundation, climate, hydrological conditions, soils, vegetation; economic use of the territory are characterized.

\section{Results and Discussion}

The landscapes of the forest-steppe were formed under conditions of insufficient moisture (the hydrothermal coefficient is 1.0) at an average annual temperature of $+0.4^{\circ} \mathrm{C}$, the average temperature in January is $-18.0^{\circ} \mathrm{C}$, in July $+19.0^{\circ} \mathrm{C}$. The sum of temperatures above $+10^{\circ} \mathrm{C}$ is $1800-1900^{\circ}$. The frost-free period lasts 120 days. An average of $335 \mathrm{~mm}$ of precipitation falls per year, of which $80-85 \%$ is during the warm period.

In the northern forest-steppe, types of terrain of divides, ridges, flat ridges, flat depressions, hillock depressions, terraces, slopes, lakes and swamps, reed swamps, ravines and girders, floodplains of large rivers, and small valleys are differentiated $[3,4]$.

I. The type of terrain of divides is mapped on the Iset-Pyshma interfluve (Isetsky district), on the Tobol - Borovaya Ingala interfluve (Uporovsky district), in the central part of the Yalutorovsky district, on the watershed plains in the upper reaches of the Bochanka, Koktyul and right tributaries of the Uk River (Zavodoukovsky district). The type of terrain of divides includes flat and wavy watershed plains covered with chernozems and gray forest soils, without noticeable signs of erosion.

The type of terrain is confined to wavy loamy watersheds with absolute heights of 80-152.6 $\mathrm{m}$ (the highest point in the Tyumen Oblast without autonomous okrugs). The area is dominated by well-drained, mostly plowed, surfaces on the site of meadows in combination with birch, birch-aspen and birch-willow forests in depressions. The lithogenic complex is formed by alluvial deposits of the third and fourth above- 
floodplain terraces and eluvial-deluvial cover deposits represented by sands, sandy loams, loams and clays. The landscape diversity is associated with the presence of a large number of depressions, valleys and the upper reaches of shallow girders [5].

The heavy-loamy variant of the type of terrain is represented by landscape units of high wavy plains with arable land in place of meadow steppes on leached chernozems and meadow saline soils in combination with birch grass forests (Convallaria majalis L., Thalictrum simplex L.) on gray forest soils. Rounded depressions are occupied by birch forests, willow bushes and low-lying sedge-grass swamps (Caltha palustris L., Phragmites australis (Cav.) Trin. ex Steud., Typha latifolia L.) on peat soils (Iset-Pyshma interfluve northwards Isetskoye village).

Within the medium-loamy variant of the type of terrain, arable land in combination with birch, birchaspen and birch-willow forest outliers on meadow-chernozem soils predominate. Fragmentary low- and medium-aged birch and birch-aspen broad-grass forests (Archangelica officinalis Hoffm., Conium maculatum L.) are distributed on dark gray forest soils.

On the Iset-Pyshma interfluve northwards Sizikovo, Barkhatovo, Arkhangelskoye villages, there are meadows and arable land on leached chernozems and meadow soils in combination with birch grass forests on gray forest soils. The landscape structure is complemented by landscape units of elongated, closed, undrained depressions with sedge-grass swamps, often overgrown with birch and willow, on peat soils.

The light-loamy variant of the type of terrain within the flat plains is represented by field and meadow landscape units on meadow saline soils in combination with birch and birch-aspen forest outliers in depressions. The landscape structure is complemented by isolated massifs of birch grass forests (Agrimonia pilosa Ledeb., Agrostis albida Trin., Athyrium filix-femina (L.) Roth) on gray forest soils (the interfluve of the Tobol and Borovaya Ingala rivers northwards Suyerka village). Flat-closed depressions with sedge-grass swampy meadows (Alopecurus arundinaceus Poir., Carex acuta L., Eleocharis palustris (L.) Roem. \& Schult.) on peat bog soils have a limited distribution.

In the conditions of the region, the landscape units of the type of terrain of divides are among the most convenient areas for agricultural development, which have been largely transformed into arable land. Grass meadows are used as hayfields and pastures. Forests are used for collecting of berries, mushrooms, and medicinal herbs, as well as for grazing livestock.

II. The type of terrain of ridges is confined to the drained watershed plains located southwards the Iset River, in the basin of the Yemurtla River, in the upper reaches of the Bochanka and Singarivers (Isetsky, Uporovsky, and Zavodoukovsky districts). Absolute heights vary from 100 to $140 \mathrm{~m}$. There are numerous deep ravines in the valley of the Kizak River. Loamy, sandy loam and sandy eluvial-deluvial and deluvial cover deposits, alluvial deposits of the third and fourth above-floodplain terraces are common. Combinations of forest landscape units and dry grass meadows are typical for ridges. Significant areas are occupied by arable land on the site of reduced forests. Swamp landscapes are rare and confined to flat-closed depressions.

By area, landscape units of medium-loamy variant with plowed meadow steppes on leached chernozems, meadow soils in combination with birch grass (Aegopodiumpodagraria L., Lactucaserriola L., Sanguisorba officinalis L.) and sedge-grass (Carex cespitosa L., Puccinellia tenuissima Litv. ex V.I. Krecz., Scirpus sylvaticus L.) forests on gray forest soils (Goryunovo and Kolesnikovo villages) are dominated. Landscapes of old-age birch sedge-grass forests on gray forest soils in combination with grass dry meadows (Medicago falcata L., Phleum pratense L., Plantago lanceolata L.) and arable lands on meadow soils (Kirsanovo village) have been formed in shallow depressions. Eastwards Bateni and Bityuki villages, landscape units of grass and sedge-grass meadows and arable lands are mapped on the site of reduced forests in combination with numerous birch and willow forest outliers on leached chernozems and gray forest soils (Lipikha and Nifaki villages).

The heavy-loamy variant is characterized by landscape units of arable lands and meadows with birch and birch-aspen forest outliers on leached chernozems in combination with birch and birch-aspen grass and sedge-grass forests on gray forest soils (Masali and Pyatkovo villages). Meadows, as a rule, are confined to the southern slopes of ridges or to the areas with clearly expressed signs of salinity [6].

The sandy loam variant is represented by landscape units of drained plains with pine and pine-birch sedge-grass (Calamagrostis canescens (Weber) Roth, Carex vaginata Tausch, Filipendula vulgaris Moench) forests on gray forest and sod-podzolic gley soils (Kirsanovo village). Within the contours of the sandy variant, under good aeration conditions, landscape units of pine and pine-birch berry-mossy (Linnaea borealis L., Lycopodium clavatum L., Rubus saxatilis L.) and grass forests on podzolic soils were formed (Kirsanovo village and Lebedevka settlement). 
In the basin of the Yuzya River, on high-plains pine-birch berry-mossy (Dryopteris filix-mas (L.) Schott, Rubus saxatilis L., Trientalis europaea L.) and grass (Calamagrostis epigeios (L.) Roth, Lathyrus pisiformis L., L. vernus (L.) Bernh., Linnaea borealis L.) and birch grass (Paris quadrifolia L., Urtica dioica L., Vicia cracca L.) forests are widely distributed on podzolic, sod-podzolic gley and gray forest soils. Near settlements and villages forests have been cut down and plowed (Bateni and Bityuki villages). In the area of Staraya Shadrina and Gubina villages, old-age pine berry-mossy forests in combination with dry grass meadows (Alopecurus pratensis L., Lotus corniculatus L., Trifolium hybridum L.) and arable lands on podzolic soils are dominated.

The forests of the type of terrain of ridges are regularly cut down. Dry meadows are used as hayfields and pastures. In the forests, residents collect berries, mushrooms, medicinal herbs. The high degree of plowing of the territory leads to a shortage of pasture lands, consequently, people use forests as pastures.

III. The type of terrain of flat ridges is formed on flat-undulating inclined plains composed of loamy alluvial deposits of the fourth above-floodplain terrace. The type of terrain is mapped on the interfluves of the left tributaries of the Iset River in the Isetsky district. The prevailing absolute heights are $80-100 \mathrm{~m}$. The relief is complicated by numerous depressions and ridges with a height difference of up to $1-5 \mathrm{~m}$. The ground water level varies from 0.5 to $5 \mathrm{~m}$. The landscape structure consists of forest landscape units in combination with dry grass meadows, some of which have been transformed into arable lands. Swamps are rare and confined to flat-closed undrained rounded, less often elongated, depressions.

The most widespread ones are the landscape units of the heavy-loamy variant. The landscape units of plains with birch grass forests (Berteroa incana (L.) DC., Chamaenerion angustifolium (L.) Scop.) on dark gray forest soils dominate. Smaller areas are occupied by grass meadows (Melilotus albus Medikus, Trifolium hybridum L., T. pratense L., Tussila gofarfara L.) and arable lands on leached chernozems. The landscape structure is complicated by numerous birch-aspen and birch-willow forest outliers on gray forest soils. Landscapes of birch grass-marsh forests and mesotrophic sedge-willow swamps on low-lying peat soils have been formed in flat-closed undrained wet depressions (Ishimsky settlement, Sozonovo village).

The medium-loamy variant is characterized by the predominance of dry-grained grass (Artemisia absinthium L., A. pontica L., Plantago major L.) meadows and arable lands on meadow soils. The landscape structure is complemented by landscape units of birch grass and sedge-grass forests on gray forest soils. Forests and meadows are used as hayfields and pastures. Forests are used for berries, mushrooms, medicinal herbs collecting. Some of the forests and meadows have been transformed into arable lands, but the total ploughing of the territory does not exceed $30 \%$.

IV. The type of terrain of flat depressions is mapped on the above-floodplain terraces of the Tobol River (Lebedevka and Zavodopetrovsky settlements, Korkino and Polyakovskaya villages), as well as in the North-West of Yalutorovsky (westwards Kiyova village) and in the East of the Uporovsky (eastwards Kiselyovo village) districts. Absolute heights vary from 110 to $140 \mathrm{~m}$. The area is dominated by arable lands in combination with meadow steppes, birch and birch-aspen forests along the depressions.

The structure of the sandy variant is dominated by landscapes of pine-birch lichen (Polygonatum odoratum (Mill.) Druce, Pulsatilla patens (L.) Mill.), berry-mossy (Chimaphila umbellata (L.) W.P.C. Barton, Fragaria vesca L., Pyrola rotundifolia L.), and grass forests on podzolic soils. The light-loamy variant includes birch grass (Geranium sylvaticum L., Pulmonaria mollis Wulfen ex Hornem.) and sedge-grass (Carex hirta L., Equisetum sylvaticum L., Filipendula ulmaria (L.) Maxim.) forests on gray forest soils.

Within the medium-loamy variant, wavy-drained surfaces with plowed meadow steppes on chernozem and meadow-chernozem soils with birch, birch-aspen and birch-willow forest outliers dominate (upper reaches of the Begila and the Uk rivers). Meadow-chernozem soils are characterized by a high humus content $(6-8 \%)$ and a close to neutral acidity (pH 6-7) [7]. The landscape units are convenient for economic development and have been mostly transformed into arable lands.

$\mathrm{V}$. The type of terrain of hillock depressions is mapped on the watershed plains in the Zavodoukovsky, Isetsky, Uporovsky, and Yalutorovsky districts. It is characterized by rounded concave depressions, often occupied by lakes. Absolute heights vary within a wide range - from 60-70 $\mathrm{m}$ in the lower reaches of the Iset River to $100-140 \mathrm{~m}$ in the South of the Isetsky and Uporovsky districts. Erosion processes are poorly expressed. The groundwater level varies widely - from 0.5 to $7-8 \mathrm{~m}$.

The landscapes of sandy and sandy loam variants include high-drained plains with pine-birch reed grass (Calamagrostis langsdorffii (Link) Trin., Melica nutans L.) and grass (Asarum europaeum L., Oxalis acetosella L.) forests on podzolic, sod-podzolic and sod-podzolic gley soils in combination with lakes (Pamyatnoye and Singul Tatarsky villages). To a lesser extent, smoothed manes with berry-mossy pine forests 
are common on podzolic (Nizhneingal and Tatarsky Singul villages) and shallow depressions with sedgegrass birch forests on sod-podzolic gley soils (Drobinino and Tyumentsevo villages). The landscapes of the loamy variant include birch reed grass and grass forests on sod-podzolic soils in combination with grass and sedge-grass meadows on chernozems.

The landscapes of the type of terrain of hillock depressions are actively used in economy. Industrial logging is carried out in the forests; residents collect berries, mushrooms, medicinal herbs. Meadows and forests are used as pastures; fishing is carried out in lakes. Part of the forest and meadow landscapes has been transformed into arable land. The combination of forest landscape units with clean lakes creates favorable conditions for the organization of recreational activities - resorts operate within the type of terrain. Within the area, two region class reserves are organized - Rafailovsky is on the right bank of the Iset River and Komissarovsky is in the upper reaches of the Yemurtla River.

VI. The type of terrain of terraces is mapped in Zavodoukovsky and Uporovsky districts on the abovefloodplain terraces of the Tobol River, as well as in the valleys of the Yemurtla, Kizak, and Koshair rivers. The flattened relief is typical; it is complicated by the remnants of the fluvial network and forms of Aeolian processing. Absolute heights vary from 60 to $100 \mathrm{~m}$. Erosion processes are poorly expressed. The ground water level varies from 3 to $10 \mathrm{~m}$. A combination of forest, meadow and swamp landscape units is characteristic.

Landscapes of the sandy variant have become the most widespread. Landscape units of drained wavy above-floodplain terraces with pine and pine-birch lichen (Antennaria dioica (L.) Gaertn., Equisetum hyemale L., Polygonatum odoratum (Mill.) Druce), heather (Calluna vulgaris (L.) Hull, Calamagrostis epigeios (L.) Roth) and berry-mossy (Fragaria vesca L., Maianthemum bifolium (L.) F.W. Schmidt, Vaccinium myrtillus L.) forests on podzolic soils dominate. The landscape structure is complemented by landscape units of pine-birch-aspen and birch reed grass (Calamagrostis epigeios (L.) Roth, C. phragmitoides Hartm., Diphasiastrum complanatum (L.) Holub) and grass (Angelica sylvestris L., Crepis tectorum L., Hieracium umbellatum L.) forests on podzolic and sod-podzolic soils that occur, in most cases, in the site of burn $[8,9]$.

The loamy variant is characterized by the predominance of landscape units of the terraces with pinebirch grass (Bromopsis inermis (Leyss.) Holub, Lathyrus pratensis L., Poapratensis ssp. pratensis, Ranunculus repens $\mathrm{L}$.) and sedge-grass (Carex vaginata Tausch, C. vulpina L.) forests on gray forest soils (upper and middle reaches of the Yemurtla River). The landscape structure is complemented by landscape units of grass meadows (Phleum phleoides (L.) H. Karst., Poa angustifolia L., Puccinellia hauptiana V.I. Krecz.) on chernozems (Berdyugino, Morevo, Slobodchiki, Staraya Nerda, and Yemurtla villages).

In many places, forests have been replaced by meadows used as hayfields and pastures. Industrial sand mining was carried out in the quarries (Tumashovsky settlement). In the South of the Zavodoukovsky district, the Komissarovsky region class reserve is organized on the above-floodplain terraces of the Yemurtla River.

VII. The type of terrain of slopes is mapped in the areas of the valleys of the Tobol, Uk, and Begila rivers and contiguous watershed plains in the Zavodoukovsky district. The landscapes are represented by slopes with an inclination of more than $3^{\circ}$. Absolute heights vary from 80 to $130 \mathrm{~m}$.

Within the type of terrain, all types of plant communities characteristics of the forest-steppe zone are found. The upper and middle parts of slopes are occupied by pine-birch berry-mossy (Fragaria vesca L., Vaccinium myrtillus L.) and grass (Angelica sylvestris L., Butomus umbellatus L.) forests on sod-podzolic soils (Zavodoukovsk town, Sungurovo village). There are also birch grass forests on gray forest soils in combination with grass meadows (Atriplex patula L., Scorzonera purpurea L., Thlaspi arvense L.) on leached chernozems and meadow soils (Markovo, Semenovo, Staraya Zaimka villages).

In the lower part of the slope, birch-aspen grass forests grow on gray forest soils (Semenovo and Staraya Zaimka villages) in combination with sedge-grass meadows on meadow salted soils (Staraya Zaimka and Yakovlevo villages). Landscape units of the type of terrain have been largely transformed into arable land. Haymaking and grazing are carried out on the meadows. Forests are used for collecting berries, mushrooms, and medicinal herbs, as well as additional pasture lands. In the past, industrial sand mining was carried out in several quarries.

VIII. The type of terrain of lakes and swamps is mapped on the flat, limited, drained above-floodplain terraces of the Tobol River in the Uporovsky and Yalutorovsky districts. It is characterized by lake-covered depressions, closed depressions with sedge-grass swamps and swampy birch woodlands. The prevailing absolute heights are $60-65 \mathrm{~m}$. The ground water level varies from 0.5 to $1.5 \mathrm{~m}$. The background landscape 
structure is formed by forest-meadow flatlands with a combination of birch sedge-grass forests, dry grass meadows and arable lands.

Typical are flat, low, undrained over-flood terraces with sedge-grass swamps (Carex vaginata Tausch, Phragmites australis (Cav.) Trin. ex Steud., Schoenoplectus lacustris (L.) Palla, Typha latifolia L.) on peat soils. To a lesser extent, grass-marsh birch forests (Equisetum palustre L., Eriophorum vaginatum L., Ledum palustre L.) are common on peat soils. In economic terms, the landscapes are poorly developed. Mostly landscape units are used as hunting grounds. Part of swamps has been transformed into arable land. Haymaking is carried out in the meadows. On the lake terrace of the Moshkara - the Moshkara regional class reserve is created.

IX. The types of terrain of reed swamps is confined to flat depressions within the lake-alluvial plains on the interfluve of the Iset and Ingala rivers (Isetsky and Yalutorovsky districts), flat above-floodplain terraces of the Tobol River (Zavodoukovsky, Uporovsky, Yalutorovsky districts). The most characteristic location of the type of terrain is flat, low, undrained terraces. Typical, in this respect, is the Zamannoye Swamp, which is located on the first over-floodplain terrace of the Tobol River in Zavodoukovsky and Yalutorovsky districts. The prevailing absolute heights are 55-60 m. Dominant landscape units are characterized by a close occurrence of groundwater and peat accumulation processes.

Sedge-willow swamps are widely distributed in combination with pine-birch forests of different ages (Ledum palustre L., Menyanthes trifoliata L., Myrtus communis L., Origanum vulgare L.) and sedgesphagnum (Carex limosa L., Equisetum palustre L.) forests. Less common are birch-willow grass-marsh, birch grass-marsh and sedge-sphagnum forests on peat soils. In economic terms, the landscape units of the type of terrain are poorly developed. Haymaking is carried out in the meadows; forests and swamps are used for collecting berries.

$\mathrm{X}$. The type of terrain of ravines and girders is mapped in the basins of the Yemurtla and Kizak rivers (Zavodoukovsky and Uporovsky districts). Large differences in relative heights $(50-70 \mathrm{~m})$ and significant slopes of the territory $(0.006-0.016)$ predetermined the intensive development of erosion processes. Ravines are constantly growing, reaching a length of $10 \mathrm{~km}$ (Masali village).

In the basin of the Kizak River, steep-walled ravines deeply embedded in heavy loam have wet bottoms with a temporary stream network. Typical are birch and birch-aspen and willow grass and sedge-grass (Carex praecox Schreb., Poa angustifolia L., Puccinellia hauptiana V.I. Krecz.) forests on gray forest soils (Masali and Markovo villages). Slightly, grass and sedge-grass meadows (Agrostis albida Trin., Carex rostrata Stokes, Festuca ovina L., F. rubra L., Phleum phleoides (L.) H. Karst.) are distributed on leached chernozems (Vidonovo village).

Steep slopes of ravines and girders are occupied by birch sedge-grass forests on sod-podzolic soils (Pyatkovo village). In gentle slope girders, pine-birch grass forests on sod-podzolic soils are common (Krasheninino and Panteleyevka villages). Sometimes ponds are created in such girders (Kolesnikovo village). Ravine and girder forests are used for collecting berries, mushrooms, medicinal herbs. In the ponds, the residents reserve water, breed fish.

XI. The type of terrain of floodplains of large rivers is differentiated in the valleys of the Iset and Tobol rivers. 1-6 km wide floodplains are composed mainly of loam, only in the area of Aslany village are mapped the landscape units of sandy variant. Absolute heights vary from 50 to $55 \mathrm{~m}$. In the structure of floodplains, the near-river, central and near-terrace floodplains are clearly differentiated. Typical are landscape units of ridges up to $5 \mathrm{~m}$ high, emerging early from flooding. Their surface is dominated by grass meadows (Bromopsis inermis (Leyss.) Holub, Filipendula ulmaria (L.) Maxim., Phleum pratense L.) on alluvial sodmeadow soils. The landscape structure is complemented by landscapes of saucer-shaped depressions with aspic sedge-grass (Agrostis stolonifera L., Allium angulosum L., Glyceria fluitans (L.) R. Br., Potentilla anserina L., Stachys palustris L.) meadows on alluvial gley soils.

In the central floodplain, ridges and flat surfaces with 3-5 $\mathrm{m}$ high in combination with inter-ridge depressions are common. The ridges are covered with grass meadows (Bromopsis inermis (Leyss.) Holub, Lathyrus pratensis L.) on alluvial turf soils. Thickets of shrubby willows and sparse forests of black poplar (Populus nigra L.) are common on the slopes of the ridges. Flat and shallow depressions are typical for the near-terraced floodplain. Landscapes of wet sedge-grass meadows were formed on peat soils. Floodplain landscape units are valuable forage lands, used as hayfields and pastures. The raised and drained floodplain areas are largely plowed. 
XII. The type of terrain of small valleys is mapped in the valleys of tributaries of the Iset and Tobol rivers. The marks of absolute heights vary widely - from 50 to $120 \mathrm{~m}$. Loamy variants predominate, only in the floodplain of the Yuzya River, sandy loam and sandy variants are common in fragments.

In the basin of the Iset River is dominated by landscapes of flat floodplains with birch and willow grass (Geranium sylvaticum L., Lathyrus pratensis L.) and sedge-grass (Carex rostrata Stokes, Phleum pratense L., Poa palustris L.) forests on gray forest and alluvial soils. Birch forests are widespread in the upper reaches of the Yemurtla River. In the floodplain, grass (Lotus corniculatus L., Melilotus officinalis (L.) Pall., Tanacetum vulgare L., Trifolium hybridum L.) and sedge-grass (Carex rostrata Stokes, Carex vaginata Tausch, Elytrigia repens (L.) Nevski) meadows on leached chernozems, meadow and alluvial soils are common. In the floodplain of the Uk River is typically a combination of willows and sedge and grass meadows on alluvial turf soils. The small-valley landscapes are mainly used as hayfields and pastures. In a number of places on the rivers, ponds have been created (Begila and Chukhonka rivers); they are used for recreational purposes.

\title{
Conclusions
}

The diversity of the forest-steppe landscapes in the southwestern part of the Tyumen Oblast is characterized by a high degree both at the level of natural complexes and at the level of landscape components. In the region, 12 types of terrain of divides, ridges, flat ridges, flat depressions, hillock depressions, terraces, slopes, lakes and swamps, reed swamps, ravines and girders, floodplains of large rivers, small valleys are differentiated and characterized in detail. Forest-steppe landscapes are convenient for economic development and have been largely transformed as a result of mainly agricultural activities and partly industrial and recreational activities. Such types of traditional nature use as gathering, hunting and fishing are paramount for residents.

\section{References}

1 Шарый П.А. Геоморфометрия в науках о земле и экологии, обзор методов и приложений / П.А. Шарый // Изв. Самар. науч. центра РАН. — 2006. - Т. 8, № 2. - С. 458-473.

2 Kotlyakov V.M. Geography: Concepts and Terms: Dictionary in five languages: Russian — English — French — Spanish — German; Russian Academy of Science / V.M. Kotlyakov, A.I. Komarova. — Moscow: Nauka, 2007. — 859 p.

3 Булатов В.И. Карта типов местности юго-востока Западно-Сибирской равнины и принципы ее составления / В.И. Булатов // Науч. зап. Воронеж. отд. Геогр. общ-ва СССР. — Воронеж, 1966. — 120 с.

4 Мильков Ф.Н. Ландшафтная география и вопросы практики / Ф.Н. Мильков. - М.: Мысль, 1966. — 256 с.

5 Козин В.В. Структура естественных ландшафтов южной сельскохозяйственной зоны Тюменской области / В.В. Козин // Вестн. Тюмен. гос. ун-та. - 1999. — № 3. - С. 3-11.

6 Иванова Н.А. К истории развития растительных ландшафтов Западной Сибири: избр. геогр. тр. / Н.А. Иванова, И.М. Крашенниников. - М.: Географгиз, 1991. - С. 558-605.

7 Каретин Л.Н. Почвы Тюменской области / Л.Н. Каретин. - Новосибирск: Наука, 1990. — 284 с.

8 Чижов В.Е. Сезонное развитие травяного покрова при непрерывной вырубке сосново-березовой лесной подзоны в Тюменской области / В.Е. Чижов // Науч. тр. Тюмен. гос. ун-т. Вып. 1. — Тюмень: Тюмен. гос. ун-т, 1976. — С. $93-103$.

9 Вегерин А.М. Комиссаровский бор / А.М. Вегерин // Тр. Ин-та экологии растений и животных. — 1967. — Вып. 53. - C. 181-205.

\section{А.В. Маршинин}

\section{Тюмень облысының орманды даласының ландшафттық әртүрлілігі (Ресей)}

\begin{abstract}
Орманды дала ландшафттары - бұл аймақтық орман және дала ландшафттарының, сондай-ақ батпақтар мен шалғындардың үйлесуіне байланысты әртүрліліктің жоғары деңгейімен сипатталатын экотоникалық жүйелер. Зерттеулер әдеби дереккөздерді, топографиялық және тақырыптық карталарды, спутниктік суреттерді, сондай-ақ 1997-2020 жылдардағы дала экспедицияларын жан-жақты талдауға

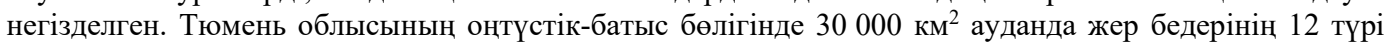
сараланған, оның ішінде бөлу рельефінің түрлері, жоталар, жазық жоталар, жазық ойпаттар, таулы ойпаттар, террастар, беткейлер, көлдер мен батпақтар, қамыс батпақтар, жартастар мен бөгеттер, ipi өзендердің алқаптары, кіші аңғарлар. Аймақтың ландшафттарын кеңістіктік ұйымдастырудың кейбір ерекшеліктері сипатталған, компоненттер деңгейіндегі ландшафт құрылымына сипаттама берілген.
\end{abstract}




\begin{abstract}
Аймақ жағдайында ландшафттардың негізгі бөлігі экономикалық даму үшін ыңғайлы және экономиканың әртүрлі салаларында қолданылады, негізінен шалғынды және дала ландшафттары, сондай-ақ жартылай жыртылған ормандар. Аумақта жайылымдар мен шабындықтар кең таралған. Құм мен шымтезек өндіру, ағаш дайындау, рекреациялық табиғатты пайдалану, сондай-ақ балық аулау, аң аулау, жинаушылық сияқты экономикалық қызмет түрлері дамыды. Кейбір ландшафттарды табиғи қорықтар сияқты мемлекет қорғайды.
\end{abstract}

Кілт сөздер: рельефтің түрі, ландшафт құрылымы, ормандыдала, Тюмень облысы.

\title{
А.В. Маршинин
}

\section{Ландшафтное разнообразие лесостепи Тюменской области (Россия)}

\begin{abstract}
Лесостепные ландшафты - экотонические системы, для которых характерна высокая степень разнообразия благодаря сочетанию зональных лесных и степных ландшафтов, а также болот и лугов. Исследования основаны на комплексном анализе литературных источников, топографических и тематических карт, спутниковых снимков, а также полевых экспедиций 1997-2020 гг. В юго-западной части

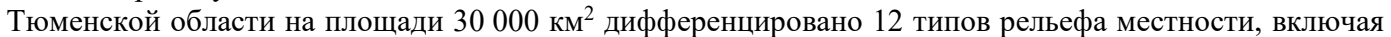
типы рельефа разделительной местности, хребтов, равнинных хребтов, равнинных впадин, холмистых впадин, террас, склонов, озер и болот, тростниковых болот, оврагов и ригелей, пойм крупных рек, малых долин. Описаны некоторые особенности пространственной организации ландшафтов региона, дана характеристика ландшафтной структуры на уровне компонентов. В условиях региона основная часть ландшафтов удобна для экономического развития и используется в различных отраслях экономики, в основном, это луговые и степные ландшафты, а также частично леса распаханы. На территории широко распространены пастбища и сенокосы. Развиты такие виды хозяйственной деятельности, как добыча песка и торфа, заготовка древесины, рекреационное природопользование, а также рыболовство, охота, собирательство. Некоторые ландшафты охраняются государством как природные заповедники.
\end{abstract}

Ключевые слова: тип местности, ландшафтная структура, лесостепь, Тюменская область.

\section{References}

1 Sharyy, P.A. (2006). Geomorfometriia v naukakh o zemle i ekologii, obzor metodov i prilozhenii [The geomorphometry in sciences of the Earth and ecology; the review of methods and applications]. Izvestiia Samarskogo nauchnogo tsentra RAN - The Bulletin of Samara scientific centre of Russian Academy of Sciences, 8 (2), 458-473 [in Russian].

2 Kotlyakov, V.M., \& Komarova, A.I. (2007). Geography: Concepts and Terms: Dictionary in five languages: Russian English - French - Spanish - German. Moscow: Nauka.

3 Bulatov, V.I. (1966). Karta tipov mestnosti yugo-vostoka Zapadno-Sibirskoi ravniny i printsipy ee sostavleniia [The map of types of terrains in the South-East of the West Siberian Plain and the principles of its compilation]. Nauchnye zapiski Voronezhskogo otdela Geograficheskogo obshchestva SSSR - Scientific notes of the Voronezh Department of the Geographical Society of the USSR. Voronezh [in Russian].

4 Milkov, F.N. (1966). Landshaftnaia geografiia i voprosy praktiki [The landscape geography and questions of practice]. Moscow: Mysl [in Russian]

5 Kozin, V.V. (1999). Struktura estestvennykh landshaftov yuzhnoi selskokhoziaistvennoi zony Tiumenskoi oblasti [The structure of natural landscapes of the southern agricultural zone of the Tyumen Oblast]. Vestnik Tiumenskogo gosudarstvennogo universiteta - Bulletin of the Tyumen State University, 3, 3-11 [in Russian].

6 Ivanova, N.A., \& Krasheninnikov, I.M. (1991). K istorii razvitiia rastitelnykh landshaftov Zapadnoi Sibiri. Izbrannye geograficheskie trudy [On the history of the development of plant landscapes in Western Siberia. Saved geographical works]. Moscow: Geografgiz, 558-605 [in Russian].

7 Karetin, L.N. (1990). Pochvy Tiumenskoi oblasti [Soils of the Tyumen Oblast]. Novosibirsk: Nauka [in Russian].

8 Chizhov, B.Ye. (1976). Sezonnoe razvitie travianogo pokrova pri nepreryvnoi vyrubke sosnovo-berezovoi lesnoi podzony v Tiumenskoi oblasti [Seasonal development of the grass cover in continuous felling of the pine-birch forest subzone in the Tyumen oblast]. Nauchnye trudy, Tiumenskii gosudarstvennyi universitet - Scientific proceedings. Tyumen State University. Issue 1. Tiumen: Tiumen State University Publishing House [in Russian].

9 Vegerin, A.M. (1967). Komissarovskii bor [Komissarovsky bor]. Trudy Instituta ekologii rastenii i zhivotnykh — Proceedings of the Institute of Plant and Animal Ecology, 53, 181-205 [in Russian]. 